\title{
傾斜した基盤上に建つ免震建物の観測と解析に基づく㧖れ振動特性 TORSIONAL VIBRATION CHARACTERISTICS OF A SEISMICALLY-ISOLATED BUILDING CONSTRUCTED ON AN INCLINED BEARING LAYER INFERRED FROM RECORDED MOTIONS AND RESPONSE ANALYSES
}

\author{
高平友 博*1, 飛田喜則 ${ }^{* 2}$, 西浦 遼*3, 上林宏敏*4, \\ 王欣 ${ }^{* 5}$, 永野正行*6 \\ Tomohiro TAKAHIRA, Yoshinori TOBITA, Ryo NISHIURA, \\ Hirotoshi UEBA YASHI, Xin WANG and Masayuki NAGANO
}

\begin{abstract}
In this paper, torsional vibration characteristics of a seismically-isolated building constructed on an inclined bearing layer are investigated based on strong motion records and microtremor measurements. In order to elucidate the generation mechanism of torsional vibration, the torsional response of the building was reproduced using a 3D-frame model of the building and a 2D-FEM model of the subsurface structure. It is found that several types of torsional vibrations were generated in different frequency ranges. The warping torsional vibration, which was generated at 6.7 $\mathrm{Hz}$, was found to be affected by the phase difference of the input motions.
\end{abstract}

Keywords : Inclined bearing layer, Torsional vibration, Strong motion records, Microtremor measurement, Seismic response analysis, Seismically isolated building 傾斜基盤，抳孔振動，強震記録，常時微動計測，地震応答解析，免震建物

\section{1. はじめに}

支持基盤の深さが一様でない地盤上に建つ建物では，長さの異な る杭基礎や直接基礎などを組み合わせた基礎形式が採用されること が多い。この場合, 基礎位置での表層地盤の層厚の違いによる地盤 増幅率の差異から，地震時には基礎部で並進振動とともに据れ振動 が励起され，水平成層地盤と異なる増幅特性が現れる 1)。さらに， 杭位置により地盤震動や上部構造の慣性力による負担せん断力の違 いが発生することから，耐震設計時にはその影響を考慮することが 重要であると指摘されている 2)。こうした背景から，傾斜した基盤 上に建つ建物について基礎の耐震性能に関する研究は数多く行われ ているが，上部構造を含めた動的挙動に関する検討は必ずしも多く

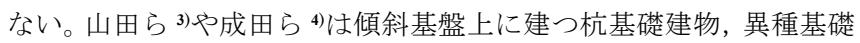
の地震時応答について, 3 次元 FEM を用いた検討を行っている。 また，遠心振動台実験により，杭支持層が傾斜した地盤上に建つ杭 基礎建物の地震応答を検討した事例も見られる5)。しかし，これら は実験や数值解析に基づく検討であり, 傾斜した基盤を有する地盤 上に建つ建物で得られた観測記録や実測に基づく検討, 特に建物応 答に関する詳細な検討はほとんど見られない。

清水建設株）（元東京理科大学大学院理工学研究科建築学専攻 修士課程

(株淺沼組名古屋支店設計部 博士 (工学)

(秼)フジタ建築本部設計統括部構造設計部

京都大学複合原子力科学研究所 准教授 - 博士 (工学)

足利大学工学部建築コース 准教授・博士 (工学)

東京理科大学理工学部建築学科 教授・博士 (工学)
筆者らは，これまで傾斜基盤を有する地盤上に建つ免震構造の実 建物を対象に，基礎位置と 1 階床の中央部，両端部で強震観測を実 施し，振動特性に関する様々な検討を行ってきた。飛田ら6) は得ら れた強震記録をもとに，強震時には免震装置が大きな㧖れ低減効果 を発揮することを明らかにした。また， 3 次元フレームモデルと地 盤の 2 次元 FEM を用いた地震応答解析により，強震記録の再現解 析を実施するとともに，傾斜基盤で場所により長さが異なる杭の応 力を評価した 7)。TAKAHIRA et al. ${ }^{8}$ は, 強震記録のシミュレーショ ン解析を踏まえ, 当該建物が耐震建物であると仮定した場合の据れ 応答の違いに着目した検討を行った。また，当該建物では基礎位置 と 1 階床のみで強震観測を行っていたことから, 西浦ら9)は上部建 物を含めた多点常時微動計測を実施し，据れ振動を含めた上部建物 の基本的な振動性状を把握した。この際，常時微動時のある卓越振 動数において，建物長辺両端部で床構面の水平動が逆位相となる鉛 直軸廻りの回転と床構面の鉛直動を伴う反りが逆位相となる曲げ変 形が連成したワーピング㧖れ振動と呼ばれる特異な㧖れ振動が励起

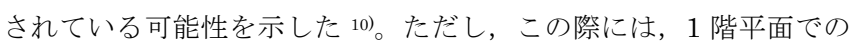
計測点数が十分でなかったこともあり，上記の㧖れ振動の可能性に

Shimizu Corporation (Former Grad. Stud., Dept. of Architecture, Tokyo Univ. of Science)

Structural Design Group, Asanuma Corporation, Dr.Eng.

Structural Design Group, Fujita Corporation

Assoc. Prof., Kyoto Univ., Dr.Eng.

Assoc. Prof., Ashikaga Univ., Dr. Eng.

Prof., Tokyo Univ. of Science, Dr.Eng. 
Table 1 Building profile

\begin{tabular}{|c|c|c|}
\hline Location & \multicolumn{2}{|c|}{ Kanagawa Prefecture } \\
\hline Use & \multicolumn{2}{|c|}{ Residential building } \\
\hline $\begin{array}{l}\text { Construction } \\
\text { area }\end{array}$ & \multicolumn{2}{|c|}{$958.6 \mathrm{~m}^{2}$} \\
\hline $\begin{array}{c}\text { Standard floor } \\
\text { area }\end{array}$ & \multicolumn{2}{|c|}{$692.6 \mathrm{~m}^{2}$} \\
\hline $\begin{array}{c}\text { Number of } \\
\text { floors }\end{array}$ & \multicolumn{2}{|c|}{6 floors } \\
\hline Height & \multicolumn{2}{|c|}{$17.55 \mathrm{~m}$} \\
\hline \multirow[b]{2}{*}{ Superstructure } & \multicolumn{2}{|c|}{$\begin{array}{c}\text { Reinforced concrete } \\
\text { (Basement: seismically-isolated structure) }\end{array}$} \\
\hline & $\begin{array}{l}\text { Longitudial direction: } \\
\text { Rigid frame structure }\end{array}$ & $\begin{array}{l}\text { Transverse direction: } \\
\text { Rigid flame structure } \\
\text { with a shear wall }\end{array}$ \\
\hline $\begin{array}{l}\text { Foundational } \\
\text { structure }\end{array}$ & \multicolumn{2}{|c|}{$\begin{array}{l}\text { Combination of a spread foundation } \\
\text { and cast-in-place concrete piles }\end{array}$} \\
\hline
\end{tabular}

ついては推測にとどまっていた。

そこで，本論文では，当該建物での抳れ振動をより詳細に把握す るために，1 階位置での計測点数を増やした多点常時微動計測を再 度実施し，強震記録と併せてワーピング㧖れ振動を含む振動特性の 分析を行う。さらに上記の据れ振動の生成要因を把握することを目 的に, 3 次元フレームモデルの基礎位置に作用する入力動を変化さ せた地震応答解析を行い, 入力動の振幅差, 位相差が, 抳れ応答の 発生に与える影響を詳細に検討する。

最初に建物の概要を示す。次に強震記録の分析を行い, 強震時に 上部構造で卓越する振動数ごとにその振動性状を確認する。より多 点で計測した常時微動記録から，上部構造で卓越する振動数ごとに 定常振動を確認し，振動性状を分析する。最後に，上部構造と免震 層からなる 3 次元フレームモデルと傾斜基盤を有する地盤の 2 次元 FEM を用いた地震応答解析を行い, この結果に基づき当該建物の 据れ応答の発生要因を考察する。

\section{2. 検討対象とする免震建物と地盤の概要}

\section{1 上部構造と強震観測の概要}

対象建物は，三浦半島北部，神奈川県逗子市に位置する 6 階建て 鉄筋コンクリート造の集合住宅である。Table 1 に対象建物の概要,

Fig. 1 に建物平面・断面概略図を示す。構造形式は 1 階と基礎の間 に免震装置（高減衰積層ゴム）を配置した基礎免震構造であり, 長辺 方向はラーメン構造, 短辺方向は耐震壁付ラーメン構造である。上 部構造は長辺方向中央でエキスパンションジョイントによって $\mathrm{A}$ 棟 と B 棟に分割されており, 本検討では強震観測を実施しているB 棟 を検討対象とする。

Fig. 1 に強震観測点を併記する。観測点は，免震層下部の基礎底 版上面 (以降, PIT と称す), 及び免震層直上の 1 階床スラブ下面 （以降， $1 \mathrm{~F}$ と称す）にそれぞれ西端部, 中央部, 東端部の計 6 点で ある。観測方向は, 中央部では短辺方向 (以降, NS と称す), 長辺 方向（EW）及び上下方向（UD）であり，両端部では NS の 1 方向 の みである。いずれも建物短辺方向の南側に設置されている。サンプ
リング周波数は $100 \mathrm{~Hz}$ である。

\section{2 地盤構造の概要}

対象建物直下の地盤構造は，主に $V \mathrm{~s}=730 \mathrm{~m} / \mathrm{s}$ の土層である支 持基盤と， $V \mathrm{~s}=140 \mathrm{~m} / \mathrm{s}$ のシルト主体の沖積層である表層地盤の 2 層地盤となっている。ボーリングデータから推定した基盤深度分布 を Fig. 1 に示す。支持基盤は敷地内で東西に傾斜しており，約 23.5 $\mathrm{m}$ の高低差を有する。また，基盤傾斜方向は建物に対して約 60 度 回転している。基礎構造は，支持基盤深さが最も浅い西端部のみ直 接基礎，それ以外の地点では支持基盤深さに応じた長さの異なる場 所打ちコンクリート杭である。東端部付近での基盤深度は GL-2 $26 \mathrm{~m}$ であり, 常時微動計測による H/V スペクトルから求められた地盤東 端部の卓越周期は約 $0.74 \mathrm{~s}^{6}$ )である。

\section{3. 強震記録の分析に基づく㧖れ振動性状}

最初に, 対象建物において 2000 年 4 月から 2017 年 8 月までに 得られた強震記録から比較的小振幅である記録を選択し，抳れ振動 を検討する。

\section{1 小振幅の強震記録の振動特性}

小振幅の強震記録として選択した地震は，最も基盤に近い PIT 西 端部における NS 方向の最大加速度が $10 \mathrm{~cm} / \mathrm{s}^{2}$ 以下，かつ高振動数 成分を多く含む震央距離が $100 \mathrm{~km}$ 以下となる 45 地震である。Fig. 2 に選択した地震の震央位置と気象庁マグニチュードを示す。

Fig. 3 に 45 地震の強震記録で得られた $1 \mathrm{~F}$ とITにおける NS 方 向のフーリエ振幅スペクトルの平均值を示す。フーリエ振幅スペク トルの平均值は，継続時間を揃えた各時刻歴加速度記録を FFT 変 換し，振動数ごとの二乗和平均の平方根とした。 $1 \mathrm{~F}$ は $1.2 \mathrm{~Hz}, 6.8$ $\mathrm{Hz}$ 付近で卓越している。1.2 Hz では基盤が深くなる東端部にかけ てやや増大するがほぼ同振幅であり， $6.8 \mathrm{~Hz}$ では中央部の振幅が小 さく両端部が大きくなっている。これらは後に示す常時微動計測で も確認されている。PIT では 1 $3 \mathrm{~Hz}$ 付近で振幅が大きく, 東端部 にかけて増大し，かつ卓越振動数が低くなっている。上部構造で見 られた $6.8 \mathrm{~Hz}$ 付近の大きな卓越は見られない。 


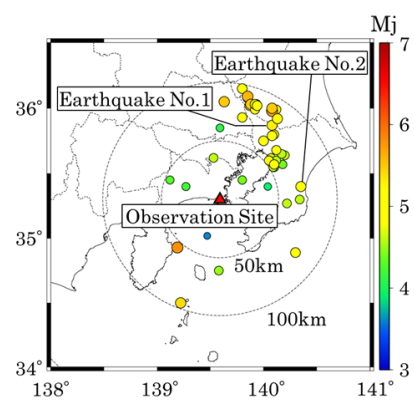

Fig. 2 Epicenter locations and magnitude $\left(\mathrm{M}_{\mathrm{j}}\right)$ of the smallamplitude earthquakes

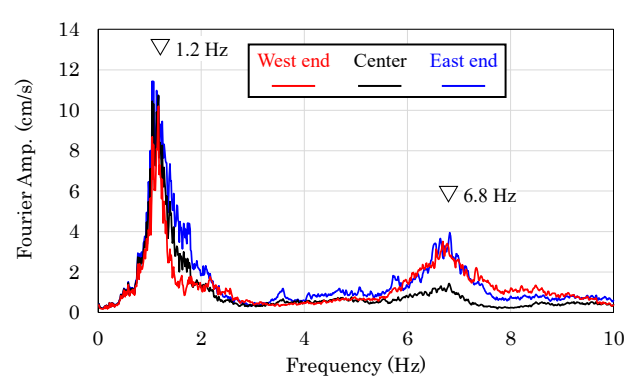

(a) $1 \mathrm{~F}$

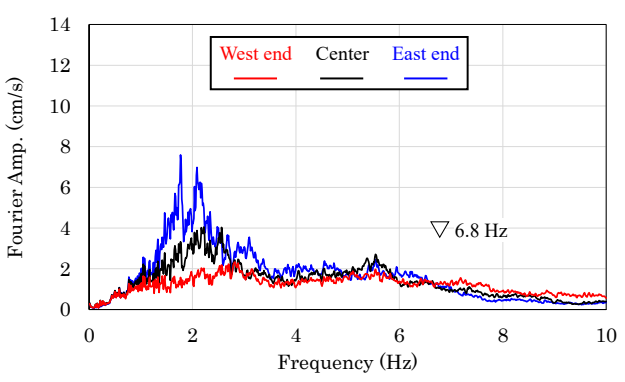

(b) PIT

Fig. 3 Average fourier amplitude spectra of using small-amplitude earthquakes records in the NS direction at (a) 1F and (b) PIT

本検討では 2003 年 5 月 12 日に千葉県北西部で発生した地震 $\left(\mathrm{M}_{\mathrm{j}} 5.3\right), 2016$ 年 7 月 19 日に千葉県北東部で発生した地震 $\left(\mathrm{M}_{\mathrm{j}} 5.2\right)$ を対象に, 㨭れ振動を詳細に分析する。(以降, それぞれを地震 No.1, 地震 No. 2 と称す。）これらの地震の概要を Table 2 に, PIT におけ る NS 方向加速度波形を Fig. 4 に示寸。Fig. 5 に地震 No.1 と地震 No.2の $1 \mathrm{~F}$ における NS 方向ランニングスペクトルと加速度波形を 西端部について示す。ランニングスペクトルは, 一区間 $10 \mathrm{~s}(1000$ step)ごとにハニングウィンドウ処理を行った後 FFT を行い, これ を $1 \mathrm{~s}$ ずつずらすことで算出した。Fig. 3 に見られた $1.2 \mathrm{~Hz}$ の卓越 振動数は両地震で共通に見られるが, 地震 No.2 では $6.8 \mathrm{~Hz}$ のピー

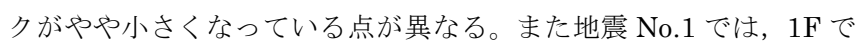
は $1.2 \mathrm{~Hz}$ 付近と $6.8 \mathrm{~Hz}$ 付近の振幅がそれぞれ最大となる時刻が概 ね一致する。地震 No.2 では, 約 20 秒から $6.8 \mathrm{~Hz}$ 付近の振幅が大き くなり, 同時間帯の $1.2 \mathrm{~Hz}$ 付近でも卓越が生じている。両地震とも それ以降の時間帯では $1.2 \mathrm{~Hz}$ 付近を主とした振動となり, $6.8 \mathrm{~Hz}$ 付近の振動は継続時間が短い傾向にある。

\section{2 卓越振動数における㨭れ振動特性}

強震記録に対し, 各卓越振動数を中心としたバンドパス処理を行 い，そのときの建物の定常応答を確認する。バンド幅は $0.2 \mathrm{~Hz}$ とす る。以降に示寸検討における全てのバンドパス処理についても同様 のバンド幅とする。

地震 No.1 の主要動部について, $1.2 \mathrm{~Hz}$ と $6.8 \mathrm{~Hz}$ における $\mathrm{NS}$ 方 向の 1 周期の応答を 8 分割して図示した結果を Fig. 6 に示す。 1.2 $\mathrm{Hz}$ では $1 \mathrm{~F}$ で NS 方向の並進振動が見られる。PIT と $1 \mathrm{~F}$ の両方で 基盤深さの増大に従って, 西端部から東端部にかけて振幅が大きく なり，並進振動に伴う㧖れ振動が生じている。6.8 Hz では $1 \mathrm{~F}$ で中 央部を中心とした捩れ振動が生じている。ただし, 建物上層階には 強震観測点が存在せず上部構造全体の振動性状を直接評価すること はできないため, 後で示す常時微動計測の結果と併せて検討する。

\section{3 最大振幅付近の西端部に対する東端部の位相差}

地震 No.1 では並進及び据れ振動の最大となる時刻が概ね一致し ていたことから，最大振幅付近の入力地震動について検討を行う。

Fig. 7 に地震 No.1の NS 方向について, $1.2 \mathrm{~Hz}$ を心としたバン ドパス加速度波形を示す。PIT では西端部から東端部にかけて振幅 が増大寸るが，位相差は小さい。1Fについても同様である。

Fig. 8 に $6.8 \mathrm{~Hz}$ を中とした $1 \mathrm{~F}$ の $\mathrm{NS}$ 方向バンドパス加速度波 形を地震 No.1 と No.2 の両方について示す。西端部に対する東端部 の位相差を 1 周期ごとに評価した結果を同図に○○で併記する。地 震 No.1ではPIT の位相差が最大で $90^{\circ}$ 程度であり, $1 \mathrm{~F}$ も両端部

\begin{tabular}{|c|c|c|c|c|c|c|c|}
\hline & \multirow{2}{*}{ Epicenter } & \multirow{2}{*}{ Date Time } & \multirow{2}{*}{$\mathrm{Mj}$} & \multirow{2}{*}{$\begin{array}{c}\text { Epicentral } \\
\text { Distance }\end{array}$} & \multicolumn{2}{|c|}{$\begin{array}{c}\text { Maximum acce. }\left(\mathrm{cm} / \mathrm{s}^{2}\right) \\
(\text { Center NS) }\end{array}$} & \multirow{2}{*}{$\begin{array}{l}\text { Max. shear } \\
\text { deformation } \\
\text { of the Isolator } \\
\text { (Center) }\end{array}$} \\
\hline & & & & & PIT & $1 \mathrm{~F}$ & \\
\hline No. 1 & $\begin{array}{c}\text { Northwestern } \\
\text { Chiba }\end{array}$ & $\begin{array}{c}2003 / 05 / 12 \\
00: 57: 58\end{array}$ & 5.3 & $78 \mathrm{~km}$ & 5.03 & 5.88 & $0.60 \%$ \\
\hline No. 2 & $\begin{array}{c}\text { Northeastern } \\
\text { Chiba }\end{array}$ & $\begin{array}{c}2016 / 07 / 19 / \\
12: 58: 14\end{array}$ & 5.2 & $70 \mathrm{~km}$ & 7.88 & 4.23 & $0.76 \%$ \\
\hline
\end{tabular}

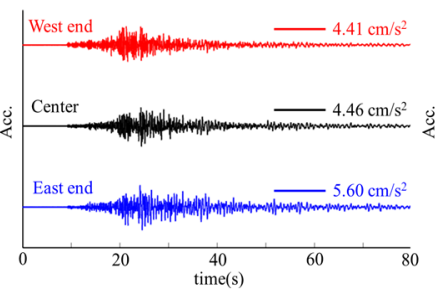

(a) Earthquake No.1

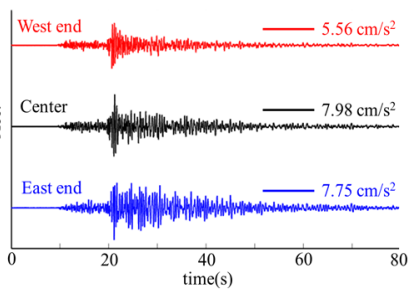

(b) Earthquake No.2
Fig. 4 Acceleration waveforms in the NS direction at PIT

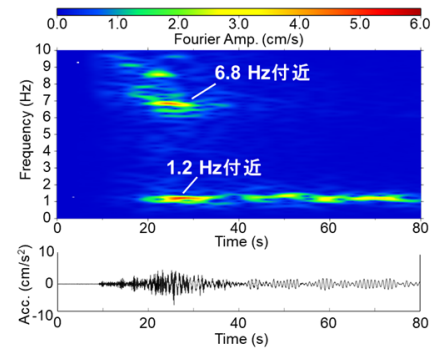

(a) Earthquake No.1

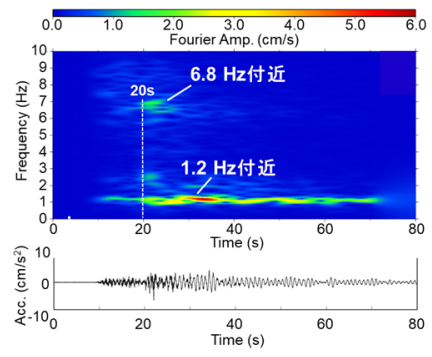

(b) Earthquake No.2
Fig. 5 Running spectra and acceleration waveforms in the NS direction at west end of $1 \mathrm{~F}$

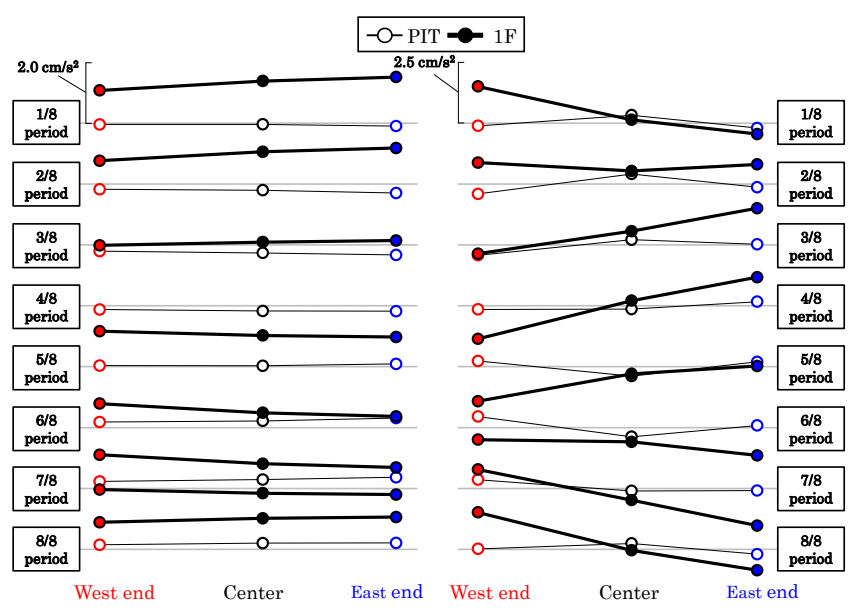

(a) $1.2 \mathrm{~Hz}$

(b) $6.8 \mathrm{~Hz}$

Fig. 6 Planar steady-state response of the $1 \mathrm{~F}$ and PIT during the Earthquake No.1 


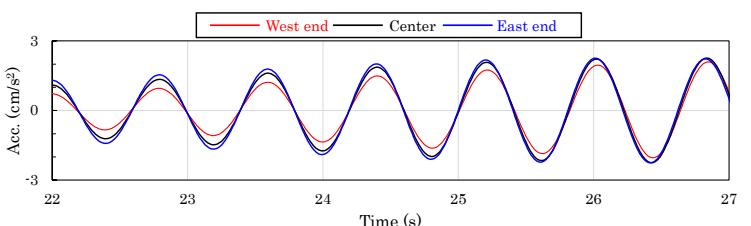

(a) $1 \mathrm{~F}$

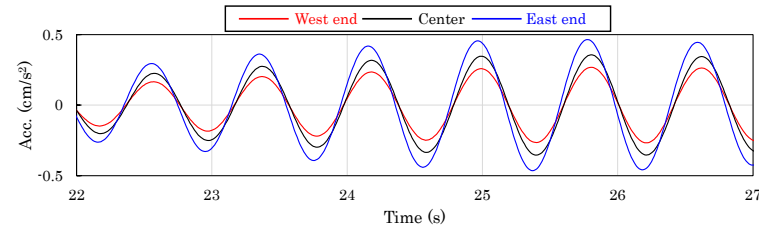

(b) PIT

Fig. 7 Bandpass-filtered (around $1.2 \mathrm{~Hz}$ ) acceleration waveforms in the NS direction of the Earthquake No.1

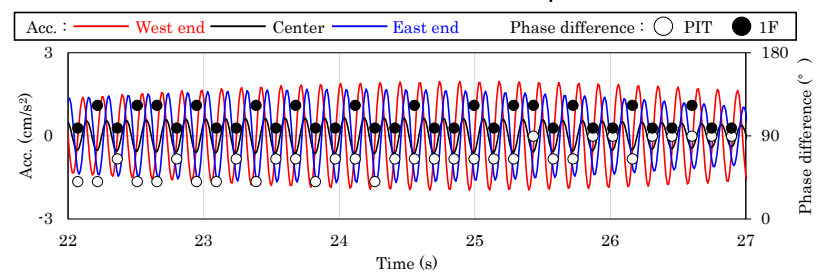

(a) Earthquake No.1

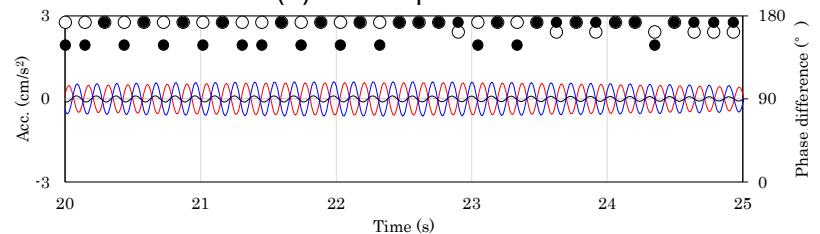

(b) Earthquake No.2

Fig. 8 Bandpass-filtered (around 6.8Hz) acceleration waveforms in the NS direction at $1 \mathrm{~F}$ and phase difference at PIT and $1 \mathrm{~F}$ of two earthquakes

が完全な逆位相ではない。これに対し地震 No.2では PIT と $1 \mathrm{~F}$ の 両端部が完全な逆位相に近い振動を示している。

\section{4. 常時微動計測に基づく掘れ振動性状}

強震記録は PIT, $1 \mathrm{~F}$ のみであったが, 多点常時微動計測を行い, PIT, $1 \mathrm{~F}$ の短辺方向両端部, 地盤, 6 階 $(6 \mathrm{~F})$ を含む振動性状を詳細 に分析する。

\section{1 常時微動計測の概要}

微動計はアカシ社製ポータブル加速度計データ収録装置 GPL$6 \mathrm{~A} 3 \mathrm{P}$ を最大 12 台（3 成分/台）と東京測振製速度計 SPC-52 を最大 9 台 (1 成分/台)用いた。計測は, サンプリング周波数を $200 \mathrm{~Hz}$ と し GPL では $20 \mathrm{~Hz}$ のハイカットフィルターを設定した。1 回の計 測時間は約 40〜50 分であり, 上部構造の振動性状を詳細に調べる ため, 計測器の位置を変え合計 3 回の計測を実施した。Table 3 に 計測概要と目的, Fig. 9 に計測器設置位置を示す。計測 No.1 は上部 構造の短辺方向のロッキング振動, 計測 No.2 は $1 \mathrm{~F}$ の詳細な平面振 動性状, 計測 No. 3 は $1 \mathrm{~F}$, PIT, 地盤面の振動性状の把握を目的と した。

\section{2 上部構造と PIT の卓越振動数}

Fig. 10 に計測 No.1 における NS 方向とUD 方向のフーリエ振幅 スペクトルを示す。フーリエ振幅スペクトルは, 交通振動や生活振 動等のノイズの少ない時間帯から 40.96 秒 (8192 step)の常時微動 部分を 20 区間抜き出し, その平均值とした。Fig. 10(a)より, 上部
構造の NS 方向の卓越振動数は, $1.3 \mathrm{~Hz}, 2.2 \mathrm{~Hz}, 4.0 \mathrm{~Hz}, 6.0 \mathrm{~Hz}$, $6.7 \mathrm{~Hz}$ である。このうち $1.3 \mathrm{~Hz}$ と $6.0 \mathrm{~Hz}$ の振動は, 西端部, 中央 部, 東端部の全点で卓越している。1.3 Hz では層厚の深い建物東端 部の振幅がやや大きくなっていることから, 㧖れを伴った並進振動 であり，前述した強震記録の傾向と整合する。一方, $2.2 \mathrm{~Hz}$ と 6.7 $\mathrm{Hz}$ の振動は, 中央部を除いた両端部で大きく卓越していることか ら，据れ振動と考えられる。また, Fig. 10(b)に示す上部構造の UD 方向でも中央部を除いた両端部で $6.7 \mathrm{~Hz}$ 付近の卓越が確認できる。 これらの卓越振動数は過去の計測 9においても確認されている。な お，Fig. 10 (a)には $4.0 \mathrm{~Hz}$ 付近に卓越振動数が見られるが，過去の 計測 9)で $\mathrm{A}$ 棟の東端部 NS 方向では $1.3 \mathrm{~Hz}, 2.2 \mathrm{~Hz}, 6.7 \mathrm{~Hz}$ に加え て $4.0 \mathrm{~Hz}$ に卓越が見られたことから，A 棟の影響と推察される。

Fig. 10(c)より, PIT の NS 方向では $6 \mathrm{~Hz}$ 付近までは表層地盤が 厚くなる東端部にかけて振幅が増大しているが，それ以降の高振動 数域では表層地盤の浅い西端部の振幅が増大寸る傾向にある。また, Fig. 10(d)より，PIT の UD 方向では $6.7 \mathrm{~Hz}$ 付近において西端部で 卓越しており, 上部構造の卓越振動数と一致する。Fig. 11 に計測 No. 3 における西端部の $1 \mathrm{~F}, \mathrm{PIT}$, 地盤面の UD 方向におけるフーリエ 振幅スペクトルを示す。 $1 \mathrm{~F}$ と PIT では計測 No.1 と同様に $6.7 \mathrm{~Hz}$ 付近で振幅の増大が見られるが, 地盤面では増大しておらず, PIT 西端部における $6.7 \mathrm{~Hz}$ の卓越は上部構造の振動によって励起され ているものと考えられる。EW 方向については，過去の計測 9によ り $1 \mathrm{~F}$ で $1.3 \mathrm{~Hz}$ と $1.9 \mathrm{~Hz}$ に卓越振動数が見られ, それより高振動 数ではピークが見られなかった。両振動数ともほぼ同位相，同振幅 で振動することを確認しており, 以降では㧖れ振動を含む複雑な振 動特性を呈する NS，UD 方向について検討する。

\section{3 各卓越振動数における㨭れ振動性状}

卓越振動数 $1.3 \mathrm{~Hz}, 2.2 \mathrm{~Hz}, 6.0 \mathrm{~Hz}$ について, PIT, $1 \mathrm{~F}$ 及び $6 \mathrm{~F}$ における 1 周期の NS 方向の定常振動を Fig. 12 に示す。 $1.3 \mathrm{~Hz}$ で は, 上部構造各階において西端部, 中央部, 東端部の 3 点でわずか に振幅差が生じている。さらに, 西端部, 中央部, 東端部それぞれ において $1 \mathrm{~F}$ と $6 \mathrm{~F}$ の振幅差はほとんど見られないことから，上部 構造がほぼ剛体として, 㧖れを伴った NS 方向並進振動を呈するこ とがわかる。 $2.2 \mathrm{~Hz}$ では, 上部構造の各階で中央部の振幅が小さく, 両端部の振幅が大きくなっており，建物中央部を中心とした㧖れ振 動が生じている。さらに, 西端部, 中央部, 東端部の振幅分布が直 線からわずかにずれており, 剛床とはやや異なる振動を呈する。ま た, $1.3 \mathrm{~Hz}$ の $\mathrm{NS}$ 方向並進振動と同様に西端部, 中央部, 東端部の それぞれで $1 \mathrm{~F}$ と $6 \mathrm{~F}$ の振幅差がほとんど見られず，高さ方向につ いて一様に振動している。6.0 Hz では, 両端部と中央部が逆位相と なる弓なりの定常振動であり, 剛床は成り立っていないが, 高さ方 向については概ね一様に振動している。

卓越振動数 $1.3 \mathrm{~Hz}$ と $2.2 \mathrm{~Hz}$ における $\mathrm{PIT}$ の $\mathrm{NS}$ 方向加速度波形 を建物北側と南側について Fig. 13 に示す。 $1.3 \mathrm{~Hz}$ では，西端部か ら東端部にかけて振幅が増大しており, わずかにずれがあるものの ほぼ同位相で振動している。また, 建物北側と南側がほぼ同位相, 同振幅で振動しており，入力において短辺方向の㧖れは生じていな いことがわかる。これより, Fig. 10(a)で見られた上部構造 NS 方向 の $1.3 \mathrm{~Hz}$ 付近における据れを伴った並進振動は入力の振幅差によ る影響が大きいと考えられる。 $2.2 \mathrm{~Hz}$ では, $1.3 \mathrm{~Hz}$ と同様に建物東 
Table 3 Outline and objectives of microtremor measurement

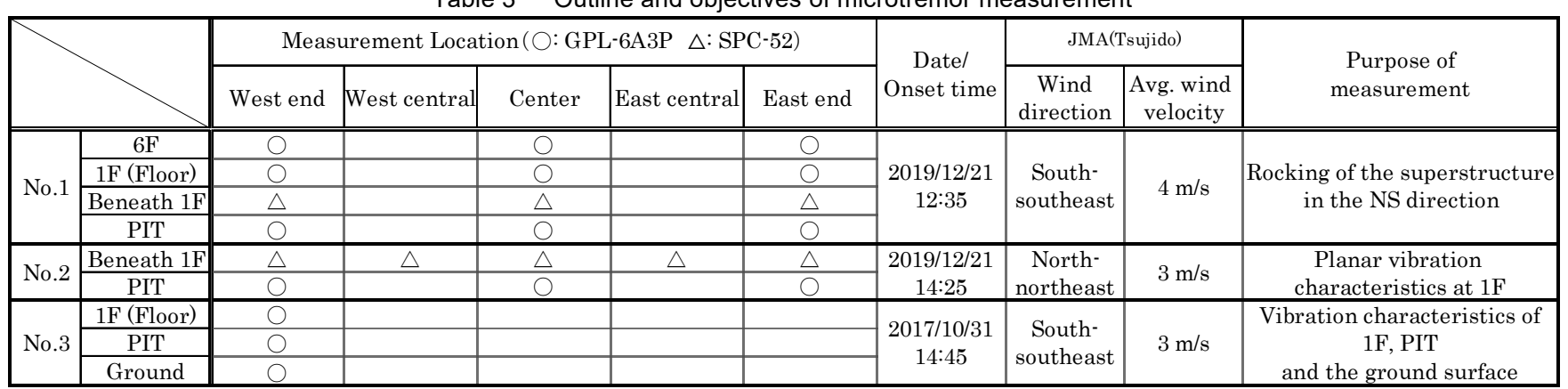

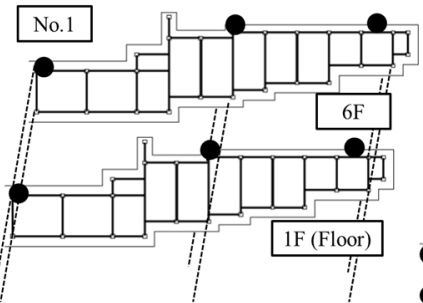

(a) Measurement No. 1

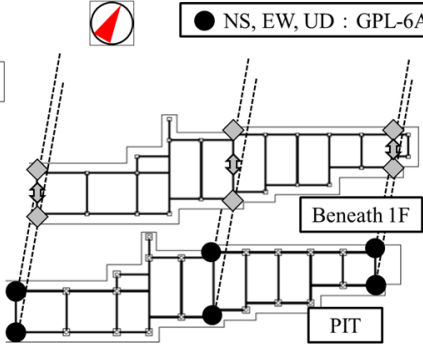

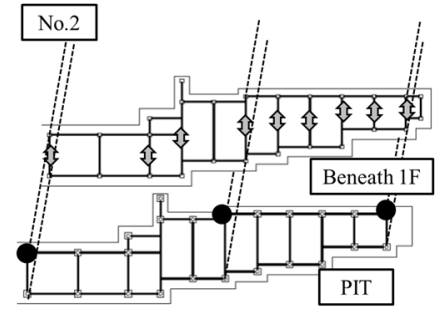

(b) Measurement No. 2

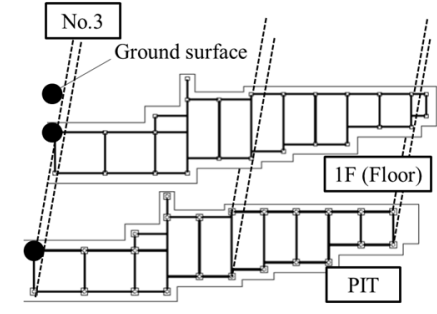

(c) Measurement No. 3

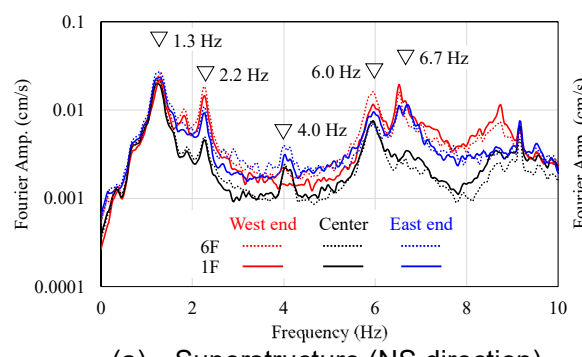

(a) Superstructure (NS direction)

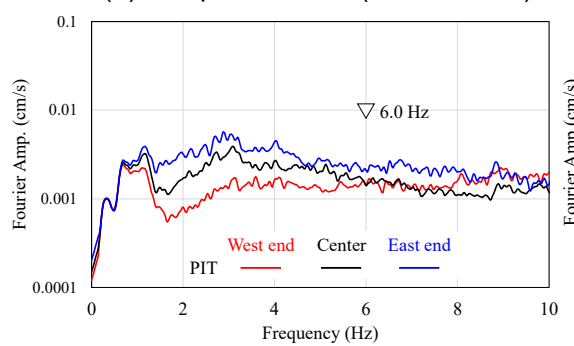

(c) PIT (NS direction)

Fig. 9 Locations of microtremor measurement

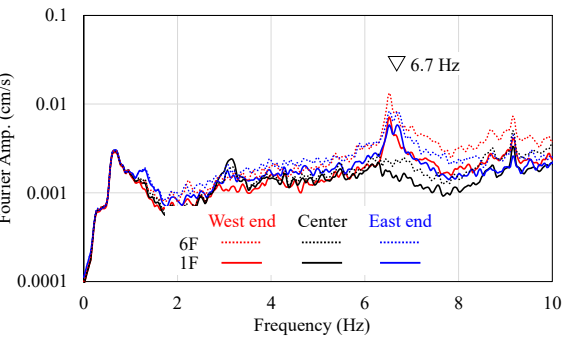

(b) Superstructure (UD direction)

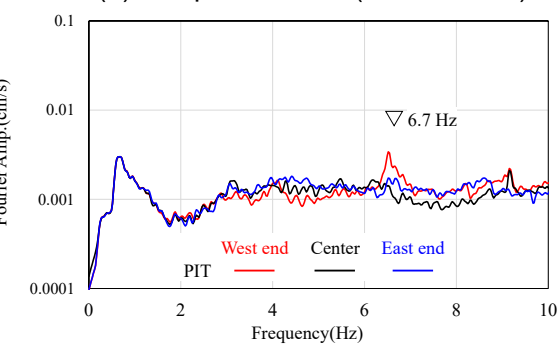

(d) PIT (UD direction)

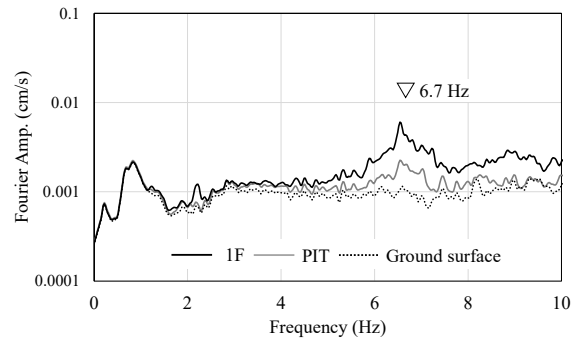

Fig. 11 Fourier amplitude spectra in the UD direction at west end obtained from measurement No.3
端部にかけて振幅が増大しており,その傾向が顕著である。さらに, 西端部から東端部にかけて位相差が生じており, 振幅差と位相差の 両方を伴う㧖れ入力になっている。

\section{4 ワーピング㧖れ振動}

計測 No.1の $1 \mathrm{~F}$ と PIT における NS 方向の加速度波形について, $6.7 \mathrm{~Hz}$ を中としたバンドパスフィルターを掛けた結果を Fig. 14 に示す。西端部に対する東端部の位相差を 1 周期ごとに評価した結 果を同図に併せて示す。1F の中央部を節として両端部と中央部が概 ね逆位相となる振動が前半約 2 秒で生じており，それ以降は中央部 の振幅が増大し, 両端部の位相差が $90^{\circ}$ 程度まで変化する。これに 対し PIT でも前半は両端部が逆位相で振動しているが, 後半にかけ て $90^{\circ}$ 程度まで変化する。

$6.7 \mathrm{~Hz}$ における平面的な挙動をより詳細に確認するため, 計測 No.2の $1 \mathrm{~F}$ における NS 方向の加速度波形について, $1 / 8$ 周期ごと
の定常振動を Fig. 15 に示す。 $1 \mathrm{~F}$ がほぼ剛床のような平面的な掘れ 振動をしており，前述したように $2.2 \mathrm{~Hz}$ の振動が剛床とはやや異 なる振動であったことと比べると, 㧖れ振動の性状が異なっている。 Fig. 14 における前半約 2 秒間の挙動に着目し, 計測 No.1 から得ら れた $1 / 8$ 周期ごとの NS, UD 方向の記録により作図した立体定常振 動を Fig. 16 に示寸。それぞれの左図にアイソメ，右図に東端部か ら見た立面を示す。この振動数では，中央部が振動しておらず，両 端部構面がほぼ逆位相にロッキング振動をしていることがわかる。 小室，井口 ${ }^{11)}$ は埋土・切土地盤上に建つ細長い建物を対象に常時微 動計測を行い，ワーピング㧖れ振動と呼ばれる特異な据れ振動が励 起されていることを示した。これは Fig.17 に示す概要図のように, 建物長辺両端部において床構面の水平動が逆位相となる鉛直軸廻り の回転と, 床構面の鉛直動を伴う反りが逆位相となる曲げ変形が連 成した変形モードである。対象建物における $6.7 \mathrm{~Hz}$ の振動はワー 


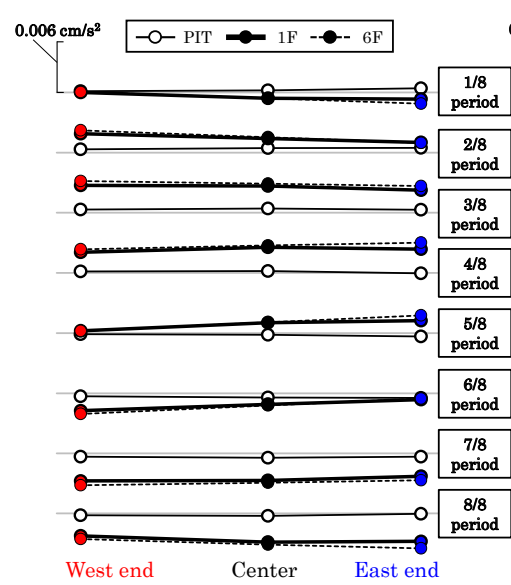

(a) $1.3 \mathrm{~Hz}$

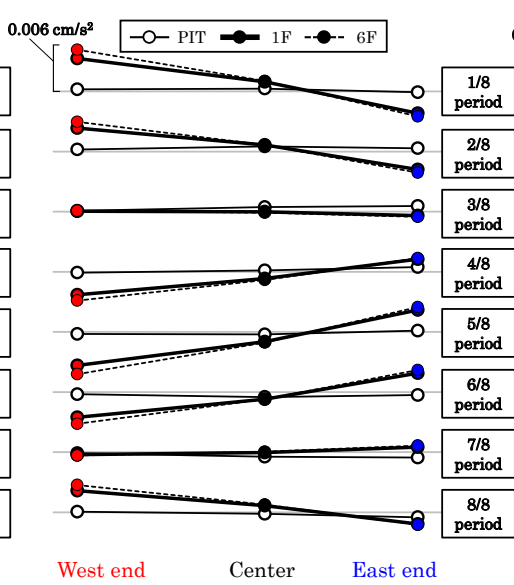

(b) $2.2 \mathrm{~Hz}$

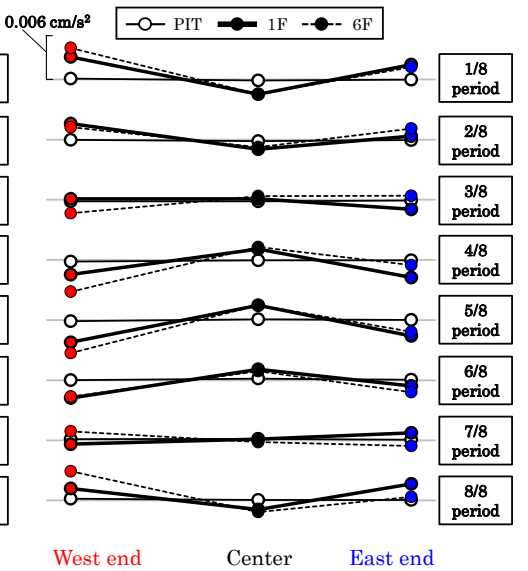

(c) $6.0 \mathrm{~Hz}$

Fig. 12 Planar steady-state vibration in the NS direction at different frequencies obtained from measurement No.1

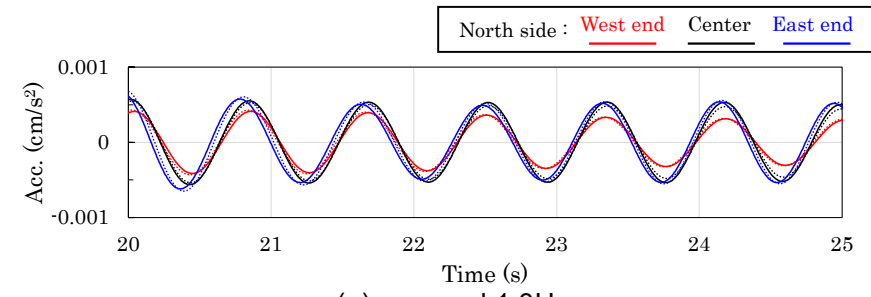

(a) around $1.3 \mathrm{~Hz}$

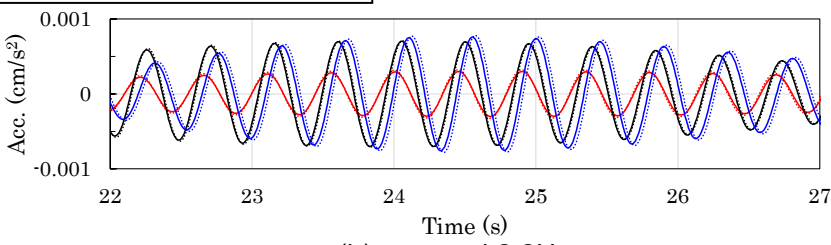

(b) around $2.2 \mathrm{~Hz}$

Fig. 13 Bandpass-filtered acceleration waveforms in the NS direction at PIT obtained from measurement No.1

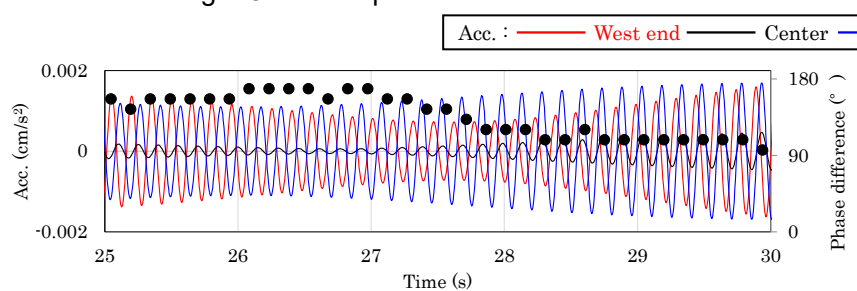

(a) $1 \mathrm{~F}$

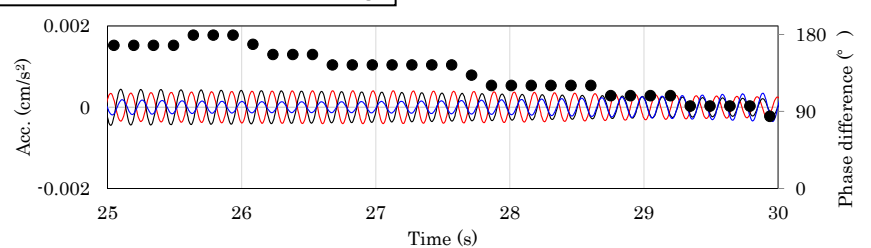

(b) PIT

Fig. 14 Bandpass-filtered (around 6.7Hz) acceleration waveforms and phase difference in the NS direction at PIT obtained from measurement No.1

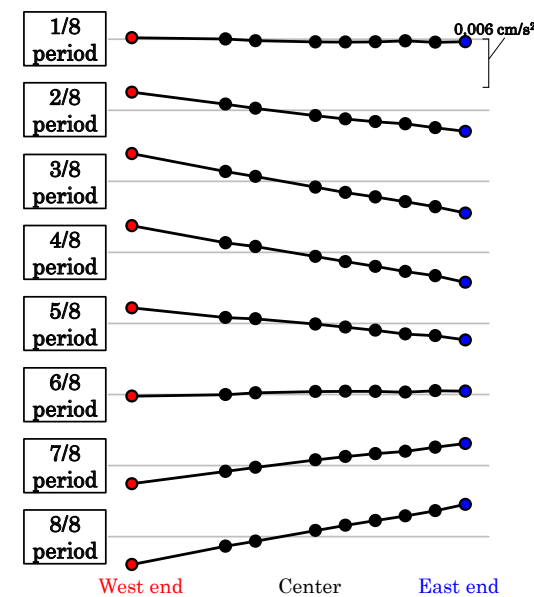

Fig. 15 Planar steady-state vibration at $6.7 \mathrm{~Hz}$ in the NS direction at $1 \mathrm{~F}$ obtained from measurement No.2

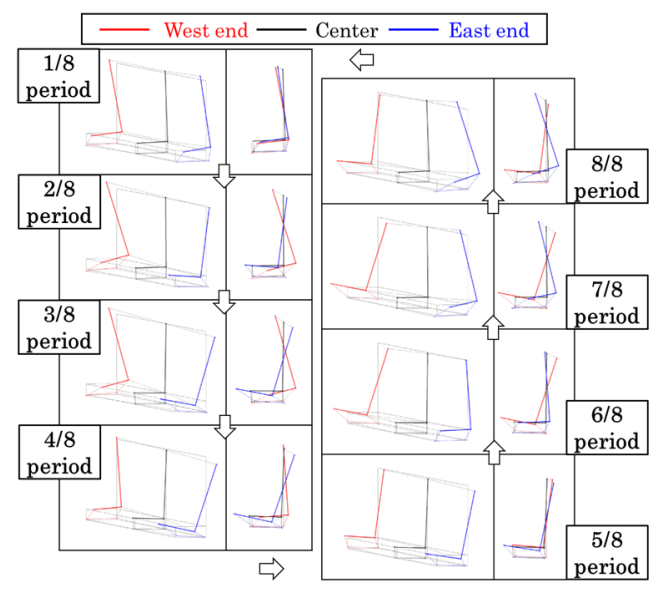

Fig. $16 \quad 3-\mathrm{D}$ steady-state vibration at $6.7 \mathrm{~Hz}$ in the NS and the UD directions obtained from measurement No.1

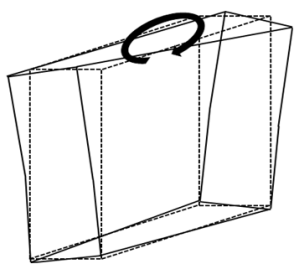

Fig. 17 Schematic diagram of warping torsional vibration ${ }^{11}$
ピング捩れ振動であると推定できる。Fig. 14 の後半では $1 \mathrm{~F}$ で中央 部の振幅が増大し, 両端部の位相差が $90^{\circ}$ 程度まで変化するものの, 上記と類似した㧖れ挙動が確認された。また, $1 \mathrm{~F} の \mathrm{NS}$ 方向の振動 が Fig. 6(b)の地震 No.1 における $6.8 \mathrm{~Hz}$ の㧖れ振動之調和的である ことから, 強震時にも並進に加えワーピング㧖れ振動が生じている 可能性がある。

当該敷地において, 地震時では下方から入射する $\mathrm{S}$ 波が表層地盤
厚さの変化により，常時微動時では水平方向へ伝播する表面波によ り，それぞれ Fig. 8, Fig. 14 に示すように，建物の東端と西端での 位相の時間遅れが発生する傾向が共通して見られる。常時微動時で は両端の位相差が $90^{\circ} \sim 180^{\circ}$ で変化しているものの, 先にも述べ たようにいずれの場合でも上部建物ではワーピング㧖れ振動もしく はそれに類似した振動が確認され，これらは建物長辺方向に沿う位 相差入力動に起因したものであると考えられる。このように，波動 
場としては地震時と常時微動時では異なるものの, 位相差入力動を 与えるという事象としては共通しているため, 次章の解析検討では 基盤層における $\mathrm{S}$ 波鉛直入射時に表層地盤の厚さが異なること等に よって生じる地表面での位相遅れを表現した入射波動場を仮定して, 据れ振動を検討する。

\section{5. 解析モデルを用いた㧖れ応答の分析}

建物の 3 次元フレームモデルと地盤の 2 次元 FEM モデルを用い て地震応答解析を行い, 基礎位置での入力動の振幅差, 位相差が上 部構造の㧖れ応答に与える影響を検討する。特に, 強震時と常時微 動時の両方で見られた $1.3 \mathrm{~Hz}$ 付近の据れを伴った並進振動と, 強 震時に発生が示唆され常時微動時にワーピング㨭れ振動を示した $6.7 \mathrm{~Hz}$ 付近の振動に注目した。

\section{1 建物モデルの概要}

建物の地震応答解析には, 免震層下部を固定とした免震装置-上部 構造からなる 3 次元フレームモデルを用いる ${ }^{12)}$ 。Fig. 18 にモデル の俯瞰図を示す。上部構造は, 柱・梁を曲げ，せん断，軸剛性を考 慮した線材, 床部材を平面板要素, 耐震壁を壁エレメント置換モデ ルで表現する。上部構造は弾性とし, 各層を非剛床とする。免震装 置の水平方向の復元力特性は, 12 本のバネからなる MSS モデルで 評価し, 既往の研究 78)13)をもとに高減衰積層ゴムの微小変形時の剛 性を考慮した標準トリリニア型とする。鉛直性能は単軸バネモデル で評価し, 設計時の剛性を用いる。並進方向での杭, 地盤との動的 相互作用は小さいものと仮定し, PIT で地震動を多点入力し, 上部 構造の㧖れ応答を検討する。

\section{2 建物モデルの固有值解析による㨝れ振動}

Table 4 に本検討における固有值解析から得られた免震装置初期 剛性時の固有振動数を示す。これより, NS 方向の並進 1 次固有振動 数は $1.29 \mathrm{~Hz}$ であり, 常時微動時の NS 方向並進振動数と対応する。 捩れの固有振動数は $1.33 \mathrm{~Hz}$ となっている。常時微動時に見られた $2.2 \mathrm{~Hz}$ とは差があるが，これは $\mathrm{A}$ 棟の影響であるものと推察される 9)。ワーピング据れ振動に対応すると推定される振動数は $6.43 \mathrm{~Hz}$ で ある。Fig. 19 に NS 方向並進 1 次固有モード図を, Fig. 20, 21 に㧖れ 振動に対応する固有モード図を示す。Fig. 21 ではワーピング㧖れ振 動に対応するモードが確認でき, 上部構造が一体となる Fig. 20 の㨭 れ 1 次モードとは異なるモード形状となっている。既報 ${ }^{10)}$ で，杭基 礎-免震装置-上部構造を各種線材に置換し, 各層を非剛床とした 3 次元フレームモデルによる固有值解析を行った結果, ワーピング据 れ振動に対応する固有モードを確認することができた。本検討では 杭基礎を含まないモデルでワーピング㨝れ振動を確認できたことか ら,この振動モードは上部構造固有のものであると推察される。

\section{3 地盤モデルの概要}

対象建物直下の地盤は, 反時計回りに 60 度回転させると 2 次元 の 2 層傾斜地盤とみな寸ことができる。この地盤を 2 次元 FEM で モデル化し, 面外 $(\mathrm{SH})$ 波と面内 $(\mathrm{SV})$ 波の鉛直入射時の 2 次元地盤 応答を周波数応答解析で評価する。 $\mathrm{S}$ 波速度 $140 \mathrm{~m} / \mathrm{s}$ に対して有効 振動数が $10 \mathrm{~Hz}$ となるようにメッシュ間隔を設定する。このモデル により中央部と東西端部の強震記録の関係が良好に再現されており 14)，建物モデルの各基礎位置の地震動を算出することが可能となっ た。解析モデル，検討の詳細は文献 7) 14)を参照のこと。

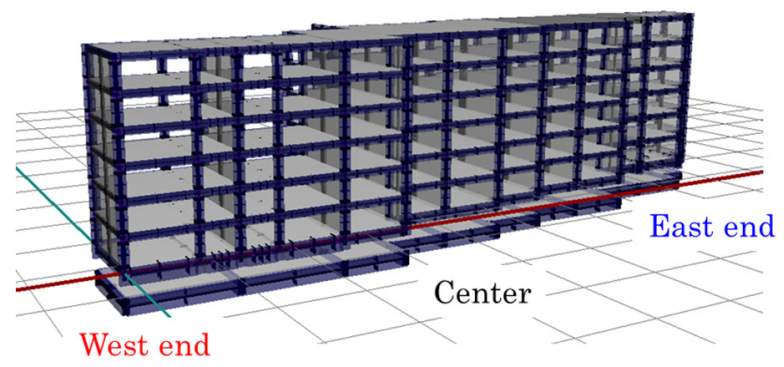

Fig. 18 Axonometric diagram of the building model

Table 4 Natural frequencies obtained from eigenvalue analysis

\begin{tabular}{|c|c|c|c|}
\hline $\mathrm{EW}$ & $\mathrm{NS}$ & Torsional & Warping torsional \\
\hline \hline $1.21 \mathrm{~Hz}$ & $1.29 \mathrm{~Hz}$ & $1.33 \mathrm{~Hz}$ & $6.43 \mathrm{~Hz}$ \\
\hline
\end{tabular}

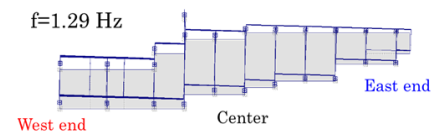

Fig. 19 Fundamental mode in NS direction

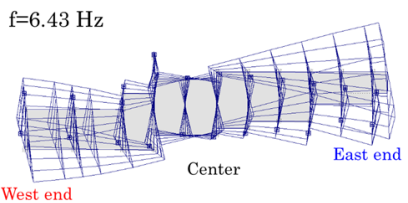

(a) Plan view

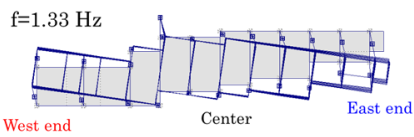

Fig. 20 Fundamental torsional mode

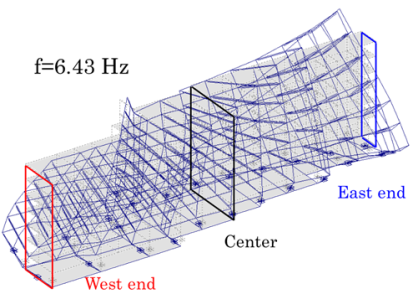

(b) Axonometric view

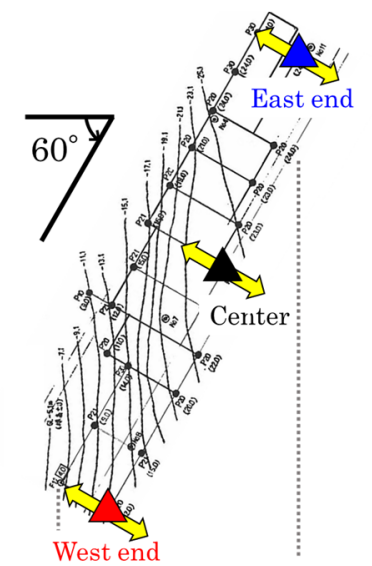

West end

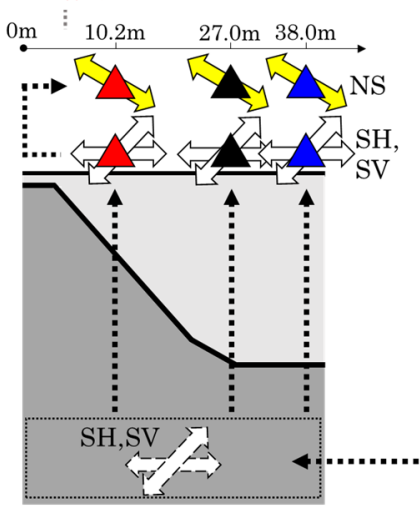

Fig. 22 Evaluation process for input motions at building basement using 2D-FEM

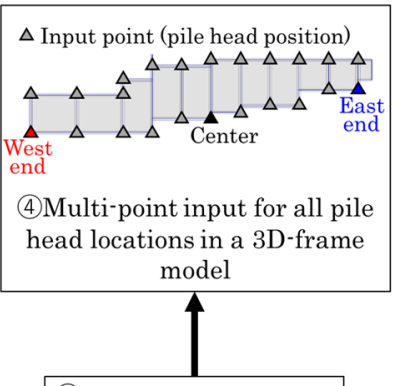

(3) Convert to building direction

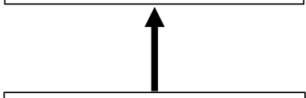

(2) Estimate SH and SV waves at any points of surface

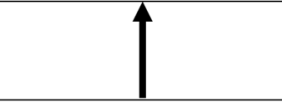

(1) Define sinewaves as bedrock waves<smiles>[N-]=CI</smiles>

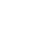




\section{4 定常波を用いた地震応答解析の概要}

常時微動計測と強震観測によって確認された上部構造の応答性状 と基盤傾斜の関連性を把握するために, 基盤波に定常波を用いた地 震応答解析を行う。Fig. 22 に解析の概略を示す。まず, 基盤波とし て NS 方向のみに振幅を有する定常波を定義し, これを $\mathrm{SH}$ 波, SV 波に分離する。次に 2 次元 FEM の面内, 面外の伝達関数を用いて 地表面の地盤応答を算出する。これらを NS 方向に変換したものを 各杭頭位置への入力地震動とし, 建物モデル全杭頭位置に多点入力 し, 上部構造の㧖れ応答を検討する。

また, 算出した地表面の応答のうち西端部を基準とし, 全杭頭位 置における振幅差と位相差を抽出し, これをパラメータとする。振 幅差と位相差を変化させた入力地震動を建物モデル全杭頭位置に多 点入力し, これらが上部構造の㧖れ応答に与える影響を分析する。

\section{5 地盤応答の振幅差, 位相差の分析}

定常波の振幅は, 基盤で NS 方向のみに振幅を有し, かつ地表西 端部の NS 方向における最大応答振幅が $1 \mathrm{~cm} / \mathrm{s}^{2}$ となるよう調整す る。Fig. 23 に設定した基盤波の加速度波形を SH, SV 波について 示す。強震時と常時微動時の両方で見られた捩れ振動について検討 するため, $1.3 \mathrm{~Hz}$ 付近と $6.7 \mathrm{~Hz}$ 付近を対象として定常波の振動数 を設定する。Fig. 23 は定常波の振動数を $1.3 \mathrm{~Hz}$ とした場合につい て示している。時間刻みは $0.001 \mathrm{~s}$ とする。Fig. 24(a)に基盤波の振 動数を $1.3 \mathrm{~Hz}$ とした場合について, 地表西端部, 中央部, 東端部の $\mathrm{NS}$ 方向応答加速度波形を示す。西端部から東端部にかけて振幅が 増大寸るが, 位相差は小さく, 強震時の $1.2 \mathrm{~Hz}$ と常時微動時の 1.3 $\mathrm{Hz}$ における PIT と同様の傾向である。Fig. 24(b)に基盤波の振動数 を $6.7 \mathrm{~Hz}$ とした場合について, 地表西端部, 中央部, 東端部の NS 方向応答加速度波形を示す。 $6.7 \mathrm{~Hz}$ では, 両端部の振幅が中央部よ りも大きい。さらに, 両端部が逆位相で振動しており, Fig. 8 で見 られた強震時における $1 \mathrm{~F}$ の中央部を節とした㨭れ振動が励起され やすい地震 No.2 の PIT の位相差と, Fig. 14 で見られた常時微動時 におけるワーピング捩れ振動が励起されやすい時間帯の PIT の位 相差と，傾向が一致する。

5.6 入力の振幅差, 位相差が上部構造の㨭れ応答に与える影響

入力が振幅差, 位相差の両方を伴う $6.7 \mathrm{~Hz}$ 付近について, 2 次元 地盤 FEM で算出した地盤応答を 3 次元フレームモデルに多点入力 し, 上部構造の捩れ応答を分析する。3 次元フレームモデルの上部 構造の減衰は剛性比例型とし, 1 階床固定時の NS 方向 1 次固有周 期に対し $h=0.03$ とする。免震装置の内部粘性減衰は, 免震層初期剛 性時の 1 次固有周期に対し $h=0.01$ とする。ここでは基盤波としての 定常波の振動数を 3 次元フレームモデルのワーピング捩れモードに 対応する $6.43 \mathrm{~Hz}$ とし, このモードに特化した検討を行う。なお, $6.43 \mathrm{~Hz}$ における地盤応答について, 前節で示した $6.7 \mathrm{~Hz}$ における 地盤応答と振幅差, 位相差の両面で傾向が変わらないことを確認し ている。地震波の入力方向は単純化のため NS 方向のみとし, 平面 的な捩れについて検討する。Fig. 25 に地震応答解析から得られる NS 方向の最大振幅分布を示す。西端部から中央部にかけて振幅が 低減し, そこから東端部にかけて増幅する。同様に位相差について も Fig. 26(a)に示す。西端部と東端部はほぼ逆位相で振動しており, その間は概ね均等に位相ずれが生じている。Fig. 27 に $6.43 \mathrm{~Hz}$ に おける地盤応答を 3 次元フレームモデルに入力したときの加速度分

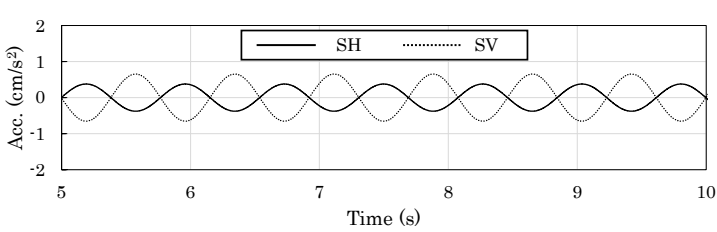

Fig. 23 Acceleration waveforms of bedrock waves

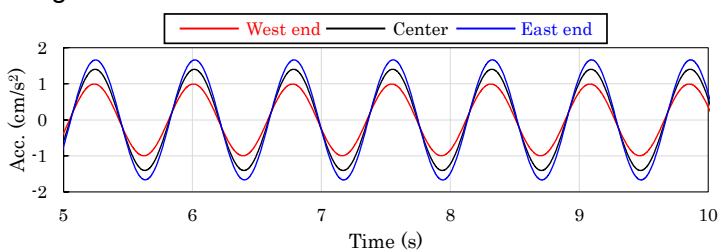

(a) $1.3 \mathrm{~Hz}$

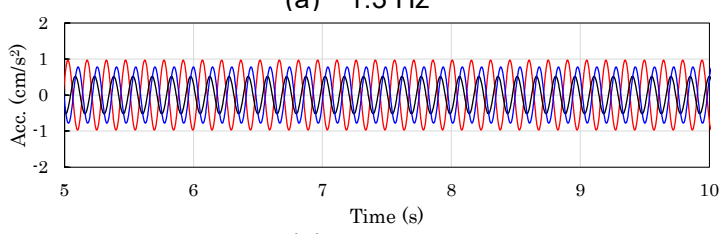

(b) $6.7 \mathrm{~Hz}$

Fig. 24 Acceleration response waveforms in the NS direction at ground surface calculated by $2 \mathrm{D}-\mathrm{FEM}$

布図を $1 \mathrm{~F}$ と屋上階 $(\mathrm{RF})$ について示す。加速度分布図は $1 \mathrm{~F}$ 東端部 の加速度の絶対值が最大となる時刻について示している。そのとき の $1 \mathrm{~F}$ 両端部の加速度を併記する。各階両端部及び端部ごとの $1 \mathrm{~F}$ と $\mathrm{RF}$ が概ね同振幅かつ逆位相で振動しており，ワーピング㧖れ振動 が生じていることがわかる。

入力の振幅差と位相差がワーピング据れ振動に与える影響につい て検討する。Fig. 25 に設定した振幅差を併せて示す。振幅差は, 2 次元 FEM の地盤応答から得られた各点の定常区間における最大振 幅を適用したものと，全点で最大振幅を $1 \mathrm{~cm} / \mathrm{s}^{2}$ に統一したものの 2 種類を設定した。Fig. 26 に設定した位相差を併せて示す。位相差 については, 2 次元 FEM による西端部の地盤応答を用いて各点に ついて均等に位相をずらし西端部と東端部が概ね $90^{\circ}$ になるよう にしたケース，同様にして西端部と東端部の位相差が概ね同位相に なるようにしたケース，全点が同位相になるようにしたケースの 3 種類を設けた。これらの組み合わせのうち，㧖れ応答の変化が明瞭 となる, Table 5 に示す 4 つの解析ケースを設定した。Fig. 28 に各 解析ケースにおける加速度分布図を $1 \mathrm{~F}$ と $\mathrm{RF}$ について示し，その ときの $1 \mathrm{~F}$ 両端部の加速度を併記する。ここでは, $1 \mathrm{~F}$ の最大加速度 がより大きい端部において加速度の絶対值が最大となる時刻につい て示している。Fig. 29 に $1 \mathrm{~F}$ と RF の西端部に対する東端部の最大 相対加速度と位相差を示す。

まず振幅差が共通で位相差が異なる case1, case 2 , case 3 の結果 を比較する。地盤両端部の位相差を $90^{\circ}$ に設定した case 1 では, Fig. 28(a)より中央部を節として各階に㧖れが生じており, そのとき の加速度には両端部で差があるものの, ワーピング㧖れ振動と調和 的な振動である。しかし, Fig. 29 より 2 次元 FEM の地盤応答を入 力した場合と比べて両端部の位相差がやや小さくなっており, PIT の位相差が両端逆位相からずれると上部構造の両端の位相差も逆位 相からずれるという強震時の Fig. 8 及び常時微動時の Fig. 14 の傾 向と一致する。入力の両端部が同位相である case 2 と case 3 につい て Fig. 28(b), (c)を見ると, やや弓なりを伴う短辺方向並進 2 次モー ドのような振動を示しており, ワーピング㧖れ振動は生じていない。 
3 次元フレームモデルの固有值解析では $6.74 \mathrm{~Hz}$ でやや弓なりを伴 う短辺方向並進 2 次モードが現れ, case 2 と case 3 ではこのモード が励起されていると考えられる。また, Fig. 29 より, case2 と case 3 は 2 次元 FEM の地盤応答を入力とした場合や case1 に比べて, 西 端部に対する東端部の位相差や最大相対加速度が小さい。位相差は あるが両端が同位相となる case2 で生じていないことも踏まえると， ワーピング㧖れ振動は入力動の位相差に大きな影響を受け，両端が 逆位相となる場合に最も励起されやすいと考えられる。

次に, 位相差を設けず, 振幅が異なる case 3 と case 4 を比較する と, Fig. 28(c), (d)よりどちらも前述の弓なりを伴う短辺方向並進 2 次モードのような振動を示しており, ワーピング据れ振動が生じて いない。これより, 振幅差だけではワーピング㨝れ振動の成因にな らないことが分かる。ここには示していないが, 振幅差がなく位相 差のみを考慮した場合の結果は, case 1,2 とほぼ同じ傾向を示す。な お，本検討では水平入力時の応答に着目したが，鉛直方向の入力の 影響については今後の検討としたい。

6. まとめ

本研究では, 傾斜基盤を有する地盤上に建つ免震建物について,
基礎位置と 1 階床で実施している強震観測とより多点に配置して実 施した常時微動計測により, ワーピング据れ振動を含む振動特性を 分析した。さらに，3 次元フレームモデルと 2 次元 FEM 地盤モデ ルを用いた地震応答解析により，記録で見られた傾向の再現と，入 力動の振幅差, 位相差をパラメータとして建物の㧖れ応答性状を調 べた。以下に, 本研究で得られた知見をまとめる。

1) 強震記録の分析により, 小振幅地震時には上部構造で $1.2 \mathrm{~Hz}$ と $6.8 \mathrm{~Hz}$ の卓越が見られた。これら 2 つ振動数における平面定常 振動は常時微動時のものと調和的であり, 強震時にも並進に加 えワーピング捩れ振動が生じている可能性がある。

2) 小振幅地震時における $6.8 \mathrm{~Hz}$ を中心とたバンドパス加速度波 形より, PIT 両端部の位相差が逆位相に近づくほど $1 \mathrm{~F}$ 両端部の 位相差も逆位相に近づく傾向が一部で見られ, 常時微動時の 6.7 $\mathrm{Hz}$ で見られた傾向と調和的であった。

3) 常時微動計測により, 上部構造では $1.3 \mathrm{~Hz}$ で短辺方向並進振動, $2.2 \mathrm{~Hz}$ で建物中央を中心とした捩れ振動, $6.0 \mathrm{~Hz}$ で建物両端部 と中央部が逆位相となる弓なりの振動, $6.7 \mathrm{~Hz}$ で建物長辺両端 部において床構面の水平動が逆位相となる鉛直軸廻りの回転と, 床構面の鉛直動を伴う反りが逆位相となる曲げ変形が連成した

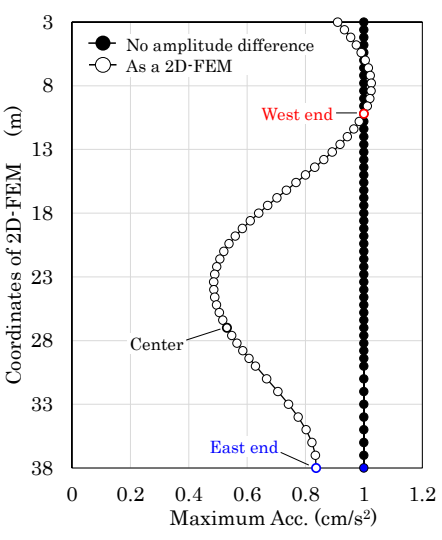

Fig. 25 Maximum acceleration on ground surface $(6.43 \mathrm{~Hz})$

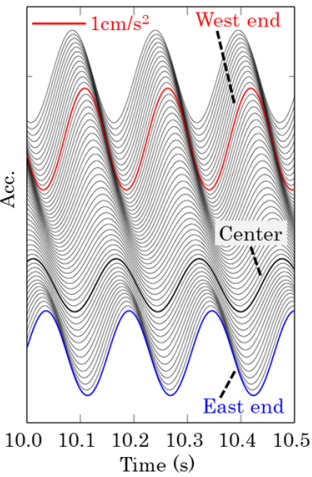

(a) Phase difference obtained by the 2D-FEM

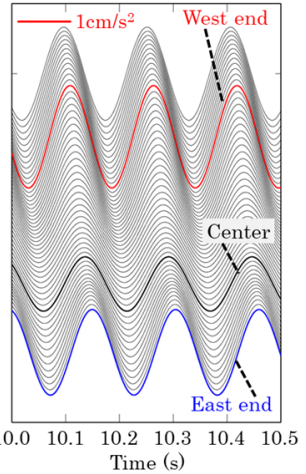

(b) Phase difference of 90 degrees between both ends

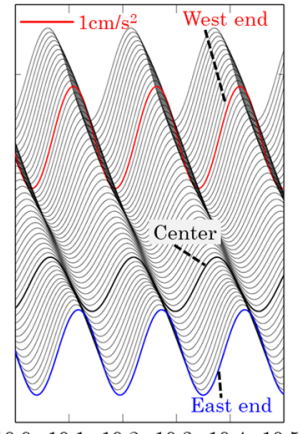

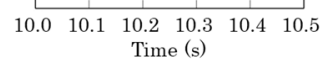

(c) Phase difference of 360 degrees between both ends

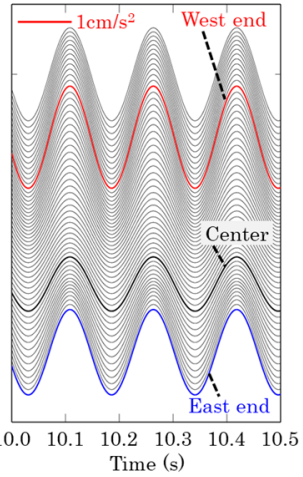

(d) No phase difference at all points

Fig. 26 Phase differences of motions on ground surface $(6.43 \mathrm{~Hz})$

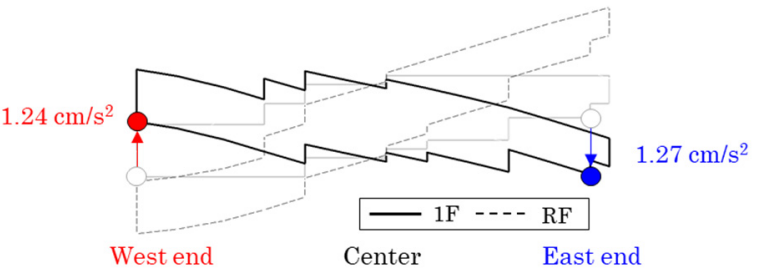

Fig. 27 Planar distribution of floor acceleration (2D-FEM)

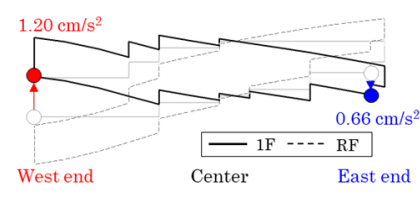

(a) case1

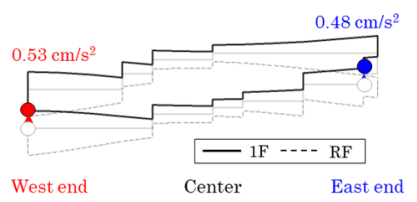

(c) case3

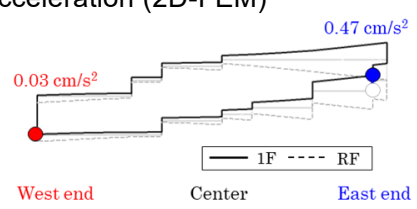

(b) case2

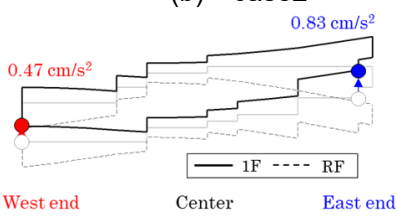

(d) case4

Fig. 28 Planar distribution of floor acceleration for each analysis cases

Table 5 Analysis cases

\begin{tabular}{|c|c|c|c|c|}
\hline & case1 & case2 & case3 & case4 \\
\hline \hline Amplitude & 2D-FEM & 2D-FEM & 2D-FEM & Constant \\
\hline $\begin{array}{c}\text { Phase } \\
\text { difference }\end{array}$ & $\begin{array}{c}\text { 90 degrees } \\
\text { between both } \\
\text { ends }\end{array}$ & $\begin{array}{c}360 \text { degrees } \\
\text { between both } \\
\text { ends }\end{array}$ & $\begin{array}{c}\text { No phase } \\
\text { difference at all } \\
\text { points }\end{array}$ & $\begin{array}{c}\text { No phase } \\
\text { difference at all } \\
\text { points }\end{array}$ \\
\hline $\begin{array}{c}\text { Correspondence } \\
\text { with Fig. 26 }\end{array}$ & (b) & (c) & (d) & (d) \\
\hline
\end{tabular}

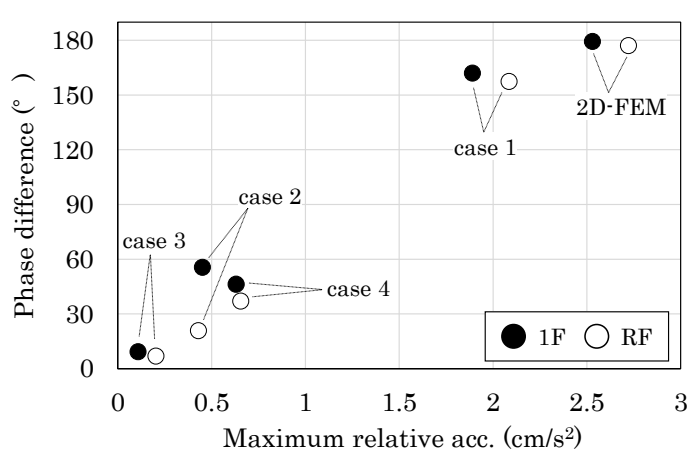

Fig. 29 Maximum relative acceleration and phase difference between west and east ends 
振動であるワーピング据れ振動が確認された。

4) 常時微動時の PIT では, $1.3 \mathrm{~Hz}$ では表層地盤が厚くなると共に 振幅が増大した。2.2 Hzではこれに加えて位相差が生じていた。 $6.7 \mathrm{~Hz}$ では両端部が逆位相となる時間帯が見られ, より高振動 数域になるほど建物に対する入力の㧖れが複雑化する傾向にあ った。

5) 上部構造と免震層からなる 3 次元フレームモデルを用いた固有 值解析により, 常時微動時と近い振動数で短辺方向並進モード とワーピング捩れモードを確認した。

6) 2 次元 FEM 地盤モデルを用い, 基盤波として定常波を用いた地 震応答解析を行った結果, 強震時, 常時微動時の $1 \mathrm{~F}$ で確認され た振動数における地盤応答の位相差は, 強震時, 常時微動時の PIT と調和的であった。

7) 強震時と常時微動時の両方で卓越が見られ, 上部構造, PIT とも に複雑な振動性状が見られた $6.7 \mathrm{~Hz}$ 付近について, 3 次元フレ ームモデルと 2 次元 FEM 地盤モデルを用いた地震応答解析に より, 入力の振幅差と位相差が上部構造の応答に与える影響を 検討した。ワーピング据れ振動を誘発する成因としては, 入力 の振幅差の影響は小さく, 両端部の位相差による影響が大きい ことがわかった。

\section{謝辞}

本研究では, 対象建物の住民の方々のご理解のもとで微動計測を 実施することができました。微動計測には淺沼組・山内豊英博士, 東京理科大学理工学部建築学科永野研究室の学生にご協力いただ きました。ワーピング㧖れ振動については, 東京理科大学名誉教授・ 井口道雄先生よりご助言を頂きました。また, 一部図の作成には GMT15)を利用させて頂きました。ここに記して感謝の意を表します。

\section{参考文献}

1) WATANABE, T., IIBA, M., KATO, K. and KOSHIKA, N.: A Fundamental Study of Effects of Inclined Engineering Bedrock on Amplification Characteristics in Surface Layer, AIJ Journal of Technology and Design, Vol.17, No.36, pp.455459, 2011.6 (in Japanese)

渡辺哲史, 飯場正紀, 加藤研一, 小鹿紀英 : 工学的基盤の傾斜が表層地盤 の増幅特性に与える影響に関する基本的検討, 日本建築学会技術報告集, 第 17 巻, 第 36 号, pp.455-459, 2011.6

2) Architectural Institute of Japan Recommendation for design of building foundations, pp.329-348, 2001 (in Japanese)

日本建築学会 : 基礎構造設計指針 2001, pp.329-348, 2001

3) YAMADA, A., MIURA, K.: Nonlinear Earthquake Response of Structure on Composite Foundation, Journal of Structural and Construction Engineering (Transactions of AIJ), No.529, pp.113-119, 2000.3 (in Japanese) 山田有孝, 三浦賢治：異種の基礎を併用した構造物の弾塑性地震応答性 状, 日本建築学会構造系論文集 第 529 号, pp.113-119, 2000.3

4) NARITA, N., YASUI, M., KANEKO O.: The Effects of Torsional Response at Composite Foundation with Piles and Footings that Affect Seismic Inertial Force of a Building, Journal of Structural and Construction Engineering (Transactions of AIJ), Vol.83, No.743, pp.101-109, 2018.1 (in Japanese)

成田修英，保井美敏，金子治：杭基礎と直接基礎を併用した異種基礎の ねじれ応答が建物の地震時慣性力に与える影響, 日本建築学会構造系論 文集 第 83 巻 第 743 号, pp.101-109, 2018.1

5) KOJIMA, H., SHOJI, M., FUJIMORI T.: Centrifuge Model Test of Pilefoundation Structure Supported by Sloping Bedrock -Part 1- Outline of Test Loaded to Sloping Direction and Pile Stress, Summaries of Technical Papers of Annual Meeting, Architectural Institute of Japan, Structure- I , pp.385-386, 2017.7 (in Japanese)

小島宏章, 勝二理智, 藤森健史 : 傾斜地盤に建つ杭基礎建物の遠心振動
台実験（その 1) 傾斜方向加振実験の概要および杭応力，日本建築学会大 会学術講演梗概集, 構造 I, pp.385-386, 2017.7

6) TOBITA, Y., NAGANO, M., KITAMURA, H., SATO, T., SUZUKI, K. MATSUDA, Y. and YAMAUCHI, T.: Study on Torsional Response of Seismically Isolated Building on Soil with Inclined Bedrock using Strong Motion Records, AIJ Journal of Technology and Design, Vol.23, No.54, pp.409-414, 2017.6 (in Japanese)

飛田喜則, 永野正行, 北村春幸, 佐藤利昭, 鈴木賢人, 松田頼征, 山内豊 英：強震記録に基づく傾斜基盤上に建つ免震建物の㧖れ応答の分析，日 本建築学会技術報告集 第 23 巻 第 54 号, pp.409-414, 2017.6

7) TOBITA, Y., NAGANO, M., KITAMURA H., YAMAUCHI, T.: Seismic Response Analysis of Seismically Isolated Building Constructed on Soil with Inclined Bedrock Based on Strong Motion Records and Evaluation of Pile Stresses, Journal of Structural and Construction Engineering (Transactions of AIJ), Vol.84, No.756, pp.149-159, 2019.2 (in Japanese)

飛田喜則，永野正行，北村春幸，山内豊英 : 強震記録に基づく傾斜基盤を 有寸る地盤上に建つ免震建物の地震応答解析と杭応力評価, 日本建築学 会構造系論文集 第 84 巻 第 756 号, pp.149-159, 2019.2

8) TAKAHIRA, T., TOBITA, Y., WANG, X., NISHIURA, R, NAGANO, M.: Torsional Responses of Buildings Constructed on Soil with Inclined Bedrock Inferred from Recorded Motions, Proceedings of $17^{\text {th }}$ World Conference on Earthquake Engineering, 17WCEE, No.2g-0039, 2020.9 (in English)

9) NiShiURA, R., NAGANO, M., TOBITA, Y., UEBAYASHI, H.: Dynamic Properties of a Seismically-Isolated Building Constructed on Soil with Inclined Bedrock from Vibration Measurements, Journal of Association for Earthquake Engineering, Vol.19, No.6 (Special issue), pp. 6-181-6-192,2019.10 (in Japanese) 西浦遼, 永野正行, 飛田喜則, 上林宏敏 : 振動計測に基づく傾斜基盤上に 建つ免震建物の振動性状に関寸る検討, 日本地震工学論文集, 第 19 巻, 第 6 号 (特集号), pp.6-181-6-192，2019.10

10) YAMAUCHI, T., TOBITA, Y., NISHIURA, R., UEBAYASHI, H., WANG, X., NAGANO, M.: Dynamic Characteristics of Seismically Isolated Building on Soil with Inclined Bedrock using Microtremor Measurement Part3 Study on the warping torsional vibration mode of superstructure, Summaries of Technical Papers of Annual Meeting, Architectural Institute of Japan, Structure- II , pp.703704, 2019.7 (in Japanese)

山内豊英, 飛田喜則, 西浦遼, 上林宏敏, 王欣, 永野正行 : 常時微動計測 に基づく傾斜基盤を有する地盤上に建つ免震建物の動特性 その 3 上部 構造のワーピング捩れ振動, 日本建築学会大会学術講演梗概集, 構造 II pp.703-704, 2019.7

11) KOMURO, T., IGUCHI, M.: Study on Dynamic Behavior of Buildings on Embedded Fill or Cut Soil Based on Microtremor Measurement, AIJ Journal of Technology and Design, Vol.13, No.26, pp.475-480, 2007.12 (in Japanese) 小室達也, 井口道雄 : 常時微動測定に基づく埋土・切土地盤上に建つ建 築物の振動性状に関する研究, 日本建築学会技術報告集, 第 13 巻, 第 26 号, pp.475-480, 2007.12

12) Kozo System, Inc.: Elasto-plastic Analysis of Arbitrary Shape 3D Frames, SNAP ver. 7 Technical Manual, 2019.4 (in Japanese)

株式会社構造システム：任意形状立体フレームの弾塑性解析 SNAP ver.7 テクニカルマニュアル, 2019.4

13) MORII, T., TAKEUCHI, S., YOSHIDA, K., SARUTA, M. and ADACHI, K.: Effect of Equivalent Stiffness of Seismic Isolation Device on Environmental Vibration Assessment. AIJ Journal of Technology and Design, Vol.21, No.49, pp.1101-1105, 2015.10 (in Japanese)

森井雄史, 竹内貞光, 吉田一博, 猿田正明, 安達一喜 : 免震部材の微小変 形時の等価剛性が環境振動評価に及ぼす影響と簡略的な応答評価法の提 案, 日本建築学会技術報告集 第 21 巻 第 49 号, pp.1101-1105, 2015.10

14) TOBITA, Y., NAGANO, M., KITAMURA H., SATOH T., SUZUKI K., YAMAUCHI, T.: Seismic response characteristics of seismically isolated building on inclined bedrock subsurface structure based on recorded motions during the 2011 Tohoku earthquake. Part 2 Simulation of ground motion by using 2D FEM and seismic response analysis of structure, Summaries of Technical Papers of Annual Meeting, Architectural Institute of Japan, Structure- II , pp.589590, 2016.7 (in Japanese)

飛田喜則, 永野正行, 北村春幸, 佐藤利昭, 鈴木賢人, 山内豊英 : 2011 年 東北地方太平洋沖地震時の観測記録に基づく傾斜基盤構造に建つ免震建 物の地震応答特性 その $2 \mathrm{FEM}$ 解析による地震動シミュレーションと建 物の地震応答解析, 日本建築学会大会学術講演梗概集, 構造 II, pp.589$590,2016.7$

15) Wessel, P., Smith, W. H. F., Scharroo, R., Luis, J. F. and Wobbe, F.: Generic Mapping Tools: Improved version released, EOS Trans. AGU, 94, 409-410, 2013 


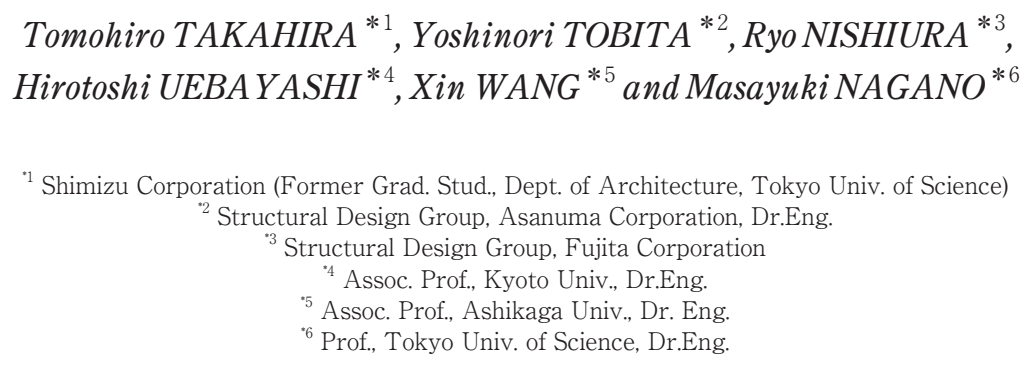

It is known that a pronounced torsional vibration is induced at buildings that are constructed on inclined bearing layers due to translational vibrations at the foundation with different amplitudes and phase characteristics during an earthquake. Although the seismic performances of the foundations of buildings constructed on inclined bearing layers have been discussed, only a few studies on the vibration characteristics of the whole building system have been performed based on observations and measurements. In this paper, the seismic-response characteristics of a seismicallyisolated building constructed on an inclined bearing layer was analyzed using strong motion records and microtremor measurements. To understand the generation mechanism of the torsional vibration of the superstructure generated by the input motion from the foundation slabs, the relationships between the torsional response and input motions from the inclined bearing layer are examined. Firstly, the strong motion records are analyzed to confirm the vibration characteristics of the superstructure. Next, the steady-state vibration of the superstructure is analyzed from the microtremor record. The vibration characteristics, including the warping torsional vibration, are confirmed for each predominant frequency of the superstructure. Finally, we analyzed the torsional response of the building by a 3D-frame model consisting of the superstructure and seismically-isolated layer and a 2D-FEM of the subsurface structure with an inclined bearing layer. The effect of the amplitude and phase difference of the input motions on the generation of the torsional response is also evaluated. The conclusions of this study are summarized as follows:

1) From the analysis of the small-amplitude earthquake records, the superstructure has predominant frequencies of 1.2 and $6.8 \mathrm{~Hz}$. The planar steady-state vibrations at these two frequencies are consistent with those of microtremors. It is possible that warping torsional vibrations as well as translation may occur during earthquakes.

2) From the microtremor measurement at the superstructure, there are a translation vibration at $1.3 \mathrm{~Hz}$, a torsional vibration around the center axis of the building at $2.2 \mathrm{~Hz}$, a bow-shaped vibration at $6.0 \mathrm{~Hz}$ (in which both ends and the center of the building are opposed to each other) and a warping torsional vibration of the building floor slab at $6.7 \mathrm{~Hz}$. The warping torsional vibration is characterized by the twisting of the mat slab of the first floor, leading to an opposite rocking behavior at both ends of the building in the short-span direction and a consequent opposite horizontal movement at the top.

3) The effects of the amplitude and phase differences of the input motions on the warping torsional responses around $6.7 \mathrm{~Hz}$ of the superstructure were examined by the 3D-frame model and the 2D-FEM ground model. The influence of the amplitude difference of the input motion is small, while the phase difference between the two ends of the building has a large influence on the inducing warping torsional vibration. 